\title{
Persepsi Investor Pemula Terhadap Pembelian Saham Syariah di Indonesia
}

\author{
Muhammad Ulinnuha1 ${ }^{*}$, Diah Eko Susilowati 2, Kharis Fadlullah Hana ${ }^{3}$ \\ ${ }^{1}$ Ekonomi Syariah, Fakultas Ekonomi dan Bisnis Islam, IAIN Kudus, ulinnuha.art2017@gmail.com \\ 2 Ekonomi Syariah, Fakultas Ekonomi dan Bisnis Islam, IAIN Kudus, diahekos@gmail.com \\ ${ }^{3}$ Ekonomi Syariah, Fakultas Ekonomi dan Bisnis Islam, IAIN Kudus, kharis@iainkudus.ac.id
}

\section{ABSTRAK}

Pasar modal telah menjadi fenomena baru di kehidupan masyarakat dunia. Dalam memutuskan berinvestasi di pasar modal, banyak faktor yang mempengaruhi, seperti persepsi atas risiko, return, ataupun nilai sesuai syariat Islam. Penelitian ini didasarkan pada fenomena masalah persepsi oleh investor yang akan berinvestasi di pasar modal, terutama dalam pembelian saham Syariah dari berbagai sudut pandang investor. Tujuan dari penelitian ini adalah untuk mengkaji dan mengembangkan sejauh mana persepsi investor pemula dalam membeli saham Syariah di Indonesia. Metode penelitian yang digunakan adalah penelitian kualitatif dengan jenis data yang digunakan adalah data primer. Teknik pengumpulan datanya yaitu mengambil sampel untuk wawancara lebih lanjut dengan sejumlah responden yang berjumlah 17 investor dari berbagai sekuritas. Sehingga peneliti dapat mengumpulkan pemecahaan permasalahan yang dialami oleh seorang investor dalam pembelian saham syariah. Hasil penelitian menunjukkan bahwa persepsi investor pemula terhadap pembelian saham Syariah di Indonesia dilihat dari beberapa indikator, seperti neutral information, accounting information, dan social relevance, yang mana ketiga indikator tersebut menghasilkan persepsi oleh investor pemula, yaitu kegiatan perusahaan berdasarkan prinsip-prinsip Syariah, sebagai bentuk dukungan dalam memajukan perekonomian Indonesia, dan pola berfikir fundamental. Sehingga akan memberikan pengaruh kepada investor pemula dalam pengambilan keputusan terhadap pembelian saham Syariah di Indonesia.
INFORMASI

ARTIKEL

Katakunci:

Investor Pemula, Keputusan Pembelian, Persepsi, Saham Syariah 


\section{Pendahuluan}

Dewasa ini, investasi sudah digalakkan oleh pemerintah, ${ }^{1}$ menjelaskan bahwa investasi merupakan pengorbanan seorang investor tanpa melihat gender investor untuk jangka waktu yang sangat panjang dan menguntungkan dalam mendapatkan nilai di masa depan yang belum dapat dipastikan besarnya. Pada ekonomi konvensional, dalam berinvestasi seseorang melakukannya dengan motif yang berbeda-beda, seperti menabung untuk mendapat pengembalian yang lebih besar, merencanakan pensiun, spekulasi, dan lain-lain. Pada investasi Syariah, merupakan bentuk investasi yang tidak hanya brupa persoalan duniawi, namun di dalamnya terdapat untur lain tentang berhasil atau tidaknya suatu investasi di masa depan, yaitu berdasarkan ketentuan dan kehendak Allah SWT yang mana bisa disebutkan sebagai investasi akhirat. Dalam Islam sendiri, investasi akhirat itu disebut shodaqoh jaariyatuh, investasi abadi, yang mana hartanya dikeluarkan di jalan Allah dalam bentuk zakat dan infak sedekah (ZIS), hadiah, hibah, serta wakaf, sehingga harta tersebut akan mengalir menjadi bermacam-macam manfaat. Investasi tersebut mengintegrasikan nilai-nilai agama yang dianut dalam melakukan investasi dengan cara melakukan seleksi dalam memilih instrumennya di pasar modal syariah. $^{2}$

1 M Betty, Susanti, and Y Yuli, "Perilaku Investor Muslimah Di Pasar Modal Syariah Di Lampung," Jurnal Bisnis Darmajaya 4, no. 1 (2018): 26-44.

2 Pramita Agustin and Imron Mawardi, “Perilaku Investor Muslim Dalam Bertransaksi
Menurut pasar modal syariah merupakan pasar yang di dalamnya ditransaksikan instrumen keuangan atau modal yang sesuai syariah dan dengan cara yang dibenarkan. 3 Pasar modal syariah telah menjadi fenomena baru di kehidupan masyarakat dunia. Sebagian besar masyarakat muslim dunia tidak dapat terlibat dalam investasi di pasar modal pada tahun 1970. Hal ini dikarenakan larangan Islam pada segala aktivitas bisnis yang tidak sesuai dengan prinsip syariah. ${ }^{4}$ Selain itu, tidak hanya investor muslim yang terjun dalam pasar modal syariah tetapi banyak investor non-muslim yang banyak memilih saham syariah karena dipandang lebih prudent. Saham syariah relatif lebih tahan terhadap dampak terjadinya gejolak ekonomi dibandingkan dengan saham reguler. Pada tahun 2015-2019 perkembangan investasi di pasar modal syariah khususnya saham syariah meningkat cukup signifikan, terlihat dari jumlah investor yang meningkat dari akhir tahun 2014 sebesar 2.705 investor menjadi 62.840 investor pada Oktober 2019. ${ }^{5}$ Hal tersebut terbukti dari tahun

Saham Di Pasar Modal," JESTT 1, no. 12 (2014): 874-892.

3 Retno Fuji Oktaviani, "Index Harga Saham Islamic Internasional Terhadap Jakarta Islamic Index," Jurnal Ekonomika Dan Manajemen 6, no. 1 (2017): 1-15.

${ }^{4}$ Pramita Agustin and Imron Mawardi, "Perilaku Investor Muslim Dalam Bertransaksi Saham Di Pasar Modal," JESTT 1, no. 12 (2014): 874-892.

${ }^{5}$ Marjudin, "BEI: Saham-Saham Syariah Mulai Jadi Incaran Banyak Investor," Ipotnews, 2019,

https://www.indopremier.com/ipotnews/new Detail.php?jdl=BEI_Saham_Syariah_Mulai_Ja di_Incaran_Banyak_Investor\&news_id $=112653 \&$ group_news $=$ IPOTNEWS\&news_date $=\&$ taging e-ISSN: $2686-6633$ 
2015-2019 terjadinya peningkatan jumlah produk saham syariah sebesar 331-421 saham. Selain itu peningkatan juga terjadi pada pertumbuhan sistem aplikasi atau Shariah Online Trading System (SOTS) yang mana per tahun 2019 sudah ada 15 anggota bursa yang memiliki sistem yang sesuai syariah. Dilihat dari statistik saham syariah yang diterbitkan OJK pertumbuhan saham reguler pada periode yang sama sebesar $46 \%$. Jika dilihat dari tingkat pertumbuhan jumlah saham syariah di periode 2015-2019 sebesar 27\%, sedangkan pada periode yang sama pertumbuhan saham reguler sebesar $16 \%{ }^{6}$

Beberapa riset terdahulu terkait Perilaku Investor dalam bertransaksi di pasar modal, diantaranya oleh Agustin \& Mawardi dengan hasil penelitian yaitu bahwa perilaku investor muslim dalam transaksi saham dibagi menjadi dua sudut pandang yaitu, investor yang mempertimbangkan agama dalam keputusan investasi mereka dan investor tidak mempertimbangkan agama dalam keputusan investasi mereka. Investor yang mempertimbangkan agama dalam keputusan investasi mereka lebih suka komposisi saham dari daftar indeks Syariah yang masuk dan sifat investasi cenderung bersifat jangka panjang. Investor yang tidak mempertimbangkan agama dalam memilih saham keputusan investasinya berpadu dengan baik dalam

subtype=MARKETOVERVIEW\&name=\&search =y_general\&q=BEI, \&halaman+1.

6 Taufan Darmawan, Nurwahidin, and Saiful Anwar, "'Analisis Faktor-Faktor Yang Memengaruhi Keputusan Investasi Di Pasar Modal Syariah,'" Jurnal Middle East and Islamic Studies 6, no. 2 (2019): 192-214. indeks yang mematuhi Syariah atau tidak. ${ }^{7}$ Sifat investasi investor yang tidak mempertimbangkan sifat jangka pendek agama. Selanjutnya, penelitian oleh Dihin Sepyato dkk. bahwa investor muslim tersebar dari segala usia dewasa dan terbesar masih ada pada kisaran umur produktif 41-45 tahun, Adapun faktor yang dominan dalam pengambilan keputusan penilaian prospek saham ada pada pengetahuan fundamental dibandingkan aspek teknikal. Adapun beberapa hal yang mempunyai pengaruh yang signifikan terhadap keputusan membeli saham syariah, seperti penilaian prospek saham yang didasarkan pada manfaat informasi harga, informasi keuangan, dan faktor yang hubungan manusia dengan Tuhannya serta hubungan dengan sesama manusia. ${ }^{8}$ Sedangkan, penelitian menurut Taufan Darmawan dkk. menunjukkan bahwa faktor literasi keuangan, nilai pribadi, dan penghindaran risiko berpengaruh terhadap keputusan investasi, sedangkan asimetri informasi tidak berpengaruh terhadap keputusan investasi. Hasil lain dari penelitian ini adalah literasi keuangan, asimetri

7 Pramita Agustin and Imron Mawardi, “JESTT Vol. 1 No. 12 Desember 2014," JESTT 1, no. 12 (2014): 874-92.

8 Dihin Septyato, Sudarwan, and Ignatius Joko Dewanto, "Model Perilaku Syariah Dalam Pengambilan Keputusan Investasi Pada Investor Muslim Di Bursa Efek Indonesia," Prosiding Seminar Nasional, 2016, 425-37, www.jp.feb.unsoed.ac.id/index.php/sca1/article/viewFile/306/311.

e-ISSN: $2686-6633$ 
informasi dan nilai pribadi tidak mempengaruhi penghindaran risiko. ${ }^{9}$

Berdasarkan penelitian-penelitian terdahulu dapat diketahui bahwa perilaku investor terhadap pembelian saham syariah di Indonesia terdapat beberapa perbedaan. Namun, sebagian besar penelitian yang dilakukan pada objek yang terbilang umum, serta belum ada penelitian yang mengkaji mengenai perilaku investor pemula terhadap pembelian saham syariah. Sehingga atas dasar tersebut yang mendasari penelitian terkait dengan perilaku investor pemula terhadap pembelian saham syariah di Indonesia. Penelitian ini bertujuan untuk mengkaji dan mengembangkan seberapa jauh persepsi investor pemula dalam melakukan pembelian saham syariah di Indonesia. Hal ini dikarenakan pandangan masyarakat umum bahwa yang membeli saham syariah hanya berasal dari investor muslim. Karena pada dasarnya tidak hanya investor muslim yang membeli saham syariah, tetapi juga bisa berasal dari investor nonmuslim.

\section{Tinjauan Pustaka}

\subsection{Persepsi}

Menurut Khreiter, dkk. menyatakan bahwa persepsi yaitu: Perception is a cognitive process that inables us to interprete and understand our surroundings. Pada dasarnya Persepsi adalah proses kognitif yang dialami oleh setiap orang dalam memahami informasi tentang lingkungannya, baik lewat penglihatan, pendengaran, penghayatan, perasaan dan penciuman. Dalam

9 Darmawan, Nurwahidin, and Anwar, "'Analisis Faktor-Faktor Yang Memengaruhi Keputusan Investasi Di Pasar Modal Syariah.'"' memahami persepsi, kuncinya adalah terletak pada pengenalan yang mana persepsi merupakan penafsiran unik terhadap situasi, dan bukan suatu pencatatan yang benar terhadap situasi. ${ }^{10}$

Menurut Schermerchon ${ }^{11}$, dkk. menjelaskan bahwa Perception the process by with people select, organize, interprete, retrieve, and respon to information from the world around them. Persepsi merupakan proses dimana seseorang memilih, mengorganisir, menginterpretasikan, mendapat kembali dan merespon informasi dari dunia di sekitarnya.

\subsection{Investasi}

Investasi adalah bentuk komitmen atas sejumlah dana yang dilakukan pada saat ini dengan tujuan mendapatkan keuntungan di masa mendatang. Investasi dibedakan menjadi dua yaitu investasi secara langsung (direct investment) dan investasi tidak langsung (indirect investment). Investasi secara langsung merupakan keterlibatan secara langsung oleh pemodal dalam kegiatan pengelolaan modal dalam jangka panjang, sedangkan investasi tidak langsung merupakan investasi dalam jangka pendek yang dilakukan pada pasar modal dan pasar uang.

Menurut Iyah Faniyah dalam penelitiannya menjelaskan bahwa pihakpihak yang melakukan investasi disebut

10 Robert Kreitner, Angelo Kinicki, and Nina Cole, Organizational Behaviour Key Concepts, Skills, and Best Practices, ed. Joanna Cotton, 2nd Canadi (McGraw-Hill Ryerson, 2003).

11 John R. Schermerchon, James G. Hunt, and Richard N. Osborn, Organizational Behavior, ed. Inc. John Wiley \& Sons, 7th ed. (United States of America, 2002). 
investor. ${ }^{12}$ Investor adalah mereka yang melakukan investasi jangka panjang yang umumnya di atas satu tahun atau lebih. ${ }^{13} \quad$ Hogan berpandapat bahwasannya predikat investor dapat disandang siapapun pada setiap lapisan masyarakat. Investor sendiri dibagi menjadi dua yaitu, investor individual (terdiri dari individu-individu yang melakukan aktivitas investasi) dan investor konstitusional (terdiri dari perusahaan asuransi, lembaga penyimpanan dana, lembaga dana pension maupun perusahaan investasi). ${ }^{14}$ Investasi pada dasarnya mempunyai prinsip utama yaitu menjaga keutuhan aset. Utuh dalam pengertian aman dan dapat memberikan tambahan imbal hasil yang minimal dapat mengimbangi faktor eksternal yang menyebabkan nilai aset menyusut 15

\subsection{Pembelian Saham Syariah}

Keputusan pembelian menurut Ian Alfian adalah bentuk pendekatan dari penyelesaian suatu masalah pada kegiatan manusia dalam membeli suatu produk untuk memenuhi keinginan dan kebutuhan. ${ }^{16}$ Sedangkan menurut Imam Heryanto keputusan pembelian yaitu proses lima tahap yang dilewati

12 Iyah Faniyah, "Investasi Syariah Dalam Pembangunan Ekonomi Indonesia," in Deepublish, 2017, 1-108.

${ }^{13}$ Belvin Tannadi and Friendy, Ilmu Saham (Binjai: PT Elex Media Komputindo, 2019).

14 Nicky Hogan, Yuk Nabung Saham (Jakarta: PT Elex Media Komputindo, n.d.).

${ }^{15}$ Nicky Hogan, Yuk Nabung Saham Selamat Datang, Investor Indonesia! (Jakarta: PT Elex Media Komputindo, 2016).

16 Ian Alfian, "Analisis Pengaruh Label Halal, Brand Dan Harga Terhadap Keputusan Pembelian Di Kota Medan," At-Tawassuth 2, no. 1 (2017): 122-45. konsumen dimulai dari pengenalan masalah, pencarian informasi, evaluasi alternatif yang dapat memecahkan masalah, keputusan pembelian, dan perilaku setelah pembelian. ${ }^{17}$ Adapun saham syariah yaitu surat berharga yang merupakan suatu bukti kepemilikan suatu perusahaan yang diterbitkan oleh emiten yang kegiatan usaha maupun tata pengelolaannya sesuai dengan prinsip syariah. Sementara dalam prinsip syariah, penyertaan modal tidak melanggar prinsip syariah, seperti riba, maisyir, serta memproduksi barang yang diharamkan. ${ }^{18}$

Dari pengertian di atas dapat disimpulkan bahwa keputusan pembelian saham syariah oleh investor yaitu menurut Agustin dan Mawardi bahwa seorang investor dalam melakukan pembelian saham dipengaruhi oleh beberapa hal yaitu mempertimbangkan agama dalam keputusan investasi mereka dan investor tidak mempertimbangkan agama dalam keputusan investasi mereka. Investor yang mempertimbangkan agama dalam keputusan investasi mereka lebih suka komposisi saham dari daftar indeks Syariah yang masuk dan sifat investasi cenderung bersifat jangka panjang. Investor yang tidak mempertimbangkan agama dalam memilih saham keputusan investasinya berpadu dengan baik dalam indeks yang mematuhi Syariah atau tidak. Sifat investasi investor yang tidak mempertimbangkan sifat jangka pendek

17 Imam Heryanto, “Analisis Pengaruh Produk, Harga, Distribusi, Dan Promosi Terhadap Keputusan Pembelian Serta Implikasinya Pada Kepuasan Pelanggan," Jurnal Ekonomi, Bisnis, \& Entrepreeurship 9, no. 2 (2015): 80-101.

18 Faniyah, "Investasi Syariah Dalam Pembangunan Ekonomi Indonesia."

e-ISSN: $2686-6633$ 
agama. ${ }^{19}$ Sedangkan menurut Dihin Sepyato bahwa faktor yang dominan dalam pengambilan keputusan penilaian prospek saham ada pada pengetahuan fundamental dibandingkan aspek teknikal. Adapun beberapa hal yang mempunyai pengaruh yang signifikan terhadap keputusan membeli saham syariah, seperti penilaian prospek saham yang didasarkan pada manfaat informasi harga, informasi keuangan, dan faktor yang hubungan manusia dengan Tuhannya serta hubungan dengan sesama manusia 20

\section{Metode Penelitian}

Penelitian ini menggunakan metode penelitian kualitatif, yang berupaya untuk menganalisis data-data yang bersifat kualitatif yang digambarkan dengan kata-kata atau kalimat dipisah-pisah menurut kategori untuk memperoleh kesimpulan. ${ }^{21}$ Penelitian ini menggunakan jenis data primer dengan kombinasi antara penelitian penjelasan (explanatory research) dan penelitian deskriptif. Teknik pengumpulan data yaitu dengan mengambil sampel untuk selanjutnya dilakukan wawancara dan dokumentasi sebagai alat pengumpulan data yang pokok atau disebut penelitian jenis survei. 22

\footnotetext{
19 Agustin and Mawardi, "Perilaku Investor Muslim Dalam Bertransaksi Saham Di Pasar Modal.”

${ }^{20}$ Septyato, Sudarwan, and Dewanto, "Model Perilaku Syariah Dalam Pengambilan Keputusan Investasi Pada Investor Muslim Di Bursa Efek Indonesia."

21 Suharismi Arikunto, Prosedur Penelitian Suatu Pendekatan Praktik (VI) (Rineka Cipta, 2010).

22 Masri Singarimbun and Sofyan Efendy, Metode Penelitian (Jakarta: Pustaka LP3S, 1993).
}

Metode penelitian ini digunakan untuk menganalisis data pernyataanpernyataan, keterangan yang bukan berupa angka, dengan mengumpulkan dan menganalisis data-data tersebut. Penulis mengumpulkan pemecahan permasalahan yang dialami oleh beberapa investor pemula dalam pembelian saham syariah di Indonesia. Penulis mengumpulkan sampel yang terdiri dari 17 informan. Dengan mengsinergikan persepsi dan aksi terhadap pembelian saham syariah di Indonesia baik dari muslim maupun non-muslim.

\section{Hasil dan Pembahasan}

Data investor dari Bursa Efek Indonesia (BEI) yang dikutip oleh CNBN Indonesia, tercatat kapitalisasi pasar sampai Maret 2020 dengan total mencapai Rp 1.582.238 Miliar, $^{23}$ dengan total investor saham syariah dengan total 72.856 atau menurut Sukri dan Amalia meningkat sebanyak $6,2 \%$ pada akhir tahun 2019,24 sebesar 68.599 investor, ${ }^{25}$ dengan kapitalisasi pasar BEI dan daftar Efek Syariah sebagai berikut:

${ }^{23}$ Haryanto, "Investasi Saham Syariah Saat Ramadan, Cuan Gak Yah?," CNBN Indonesia, 2020, https://www.cnbnindonesia.com/syariah/2020042913 5923-29-155260/investasi-saham-syariah-saatramadan-cuan-gak-yah.

24 Sukri Harahap and Amelia Murni, "Kinerja Pasar Modal Syariah Tetap Positif Di Tengah Pandemi Corona," Kitakini.news, 2020, https://kitakini.news/58165/kinerja-pasar-modalsyariah-tetap-positif-di-tengah-pandemi-corona.

25 Novita Intan, "Investasi Syariah Meningkat, BEI Kantongi 70.132 Investor," Republika.co.id, 2020, https://republika.co.id/berita/q650zz370/investasisyariah-meningkat-bei-kantongi-70132-investor.

e-ISSN: $2686-6633$ 
Jurnal Ilmu Ekonomi dan Bisnis Islam - JIEBI

Vol. 2 No. 1 Tahun 2020

syariah Indonesia tahun 2019 sebanyak 3.774.816,32 dan pada Januari 2020

\begin{tabular}{|c|c|c|c|c|}
\hline \multicolumn{5}{|c|}{ KAPITALISASI PASAR BURSA EFEK INDONESIA } \\
\hline \multirow{2}{*}{\multicolumn{2}{|c|}{ TAHUN }} & \multicolumn{2}{|c|}{ (Rp Miliar) } & \multirow[b]{2}{*}{$\begin{array}{r}\text { JAKARTA } \\
\text { ISLAMIC INDEX } 70\end{array}$} \\
\hline & & $\begin{array}{l}\text { JAKARTA } \\
\text { ISLAMIC INDEX }\end{array}$ & $\begin{array}{c}\text { INDEKS } \\
\text { SAHAM SYARIAH } \\
\text { INDONESIA }\end{array}$ & \\
\hline 2000 & & $74.268,92$ & - & - \\
\hline 2001 & & $87.731,59$ & - & - \\
\hline 2002 & & $92.070,49$ & - & - \\
\hline 2003 & & $177.781,89$ & - & - \\
\hline 2004 & & $263.863,34$ & - & - \\
\hline 2005 & & $395.649,84$ & - & - \\
\hline 2006 & & $620.165,31$ & - & - \\
\hline 2007 & & $1.105 .897,25$ & - & - \\
\hline 2008 & & $428.525,74$ & - & - \\
\hline 2009 & & $937.919,08$ & - & - \\
\hline 2010 & & $1.134 .632,00$ & - & - \\
\hline 2011 & & $1.414 .983,81$ & $1.968 .091,37$ & - \\
\hline 2012 & & $1.671 .004,23$ & $2.451 .334,37$ & - \\
\hline 2013 & & $1.672 .099,91$ & $2.557 .846,77$ & - \\
\hline 2014 & & $1.944 .531,70$ & $2.946 .892,79$ & - \\
\hline 2015 & & $1.737 .290,98$ & $2.600 .850,72$ & - \\
\hline 2016 & & $2.035 .189,92$ & $3.170 .056,08$ & - \\
\hline 2017 & & $2.288 .015,67$ & $3.704 .543,09$ & - \\
\hline 2018 & & $2.239 .507,78$ & $3.666 .688,31$ & $2.715 .851,74$ \\
\hline 2019 & & $2.318 .565,69$ & $3.744 .816,32$ & $2.800 .001,49$ \\
\hline \multirow[t]{3}{*}{2020} & Januari & $2.134 .960,15$ & $3.464 .489,36$ & $2.574 .301,02$ \\
\hline & Februari & $1.876 .573,15$ & $3.139 .077,45$ & $2.283 .779,96$ \\
\hline & Maret & $1.582 .238,00$ & $2.688 .657,92$ & $1.899 .060,82$ \\
\hline
\end{tabular}

Sumber: $\underline{w w w . o j k . c o . i d}$

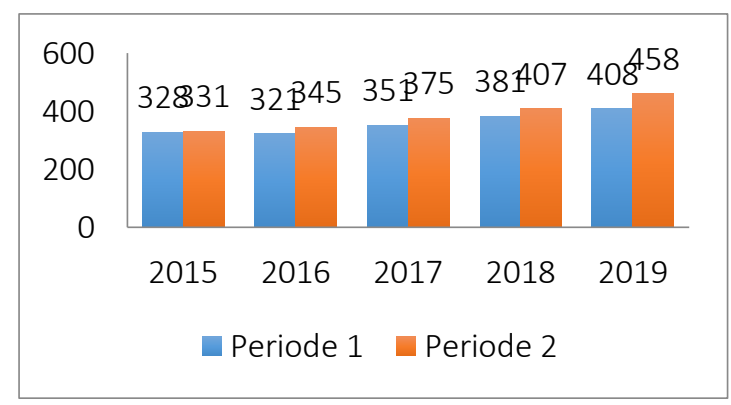

sumber: www.ojk.co.id

Adapun JII pada tahun 2019 2.318.015, 78 dan pada Januari 2020 sebesar 2.134.960,15, pada Maret 2020 sebesar 1.582.238,00, indeks saham sebesar 3.464.489,36, sedangkan pada Maret 2020 sebesar 2.688.657,92, serta Jakarta Islamic Indeks 70 di tahun 2019 sebesar 2.800.001,49 dan per Maret 2020 sebanyak 1.899.060,82. ${ }^{26}$

Naik turunnya investor dalam berinvestasi di saham Syariah dipengaruhi adanya persepsi investor dalam menentukan pembeliannya. Oleh karena itu, setelah dilakukannya wawancara secara mendalam terhadap ketujuh belas informan diperoleh hasil

26 Direktorat Pasar Modal Syariah and Otoritas Jasa Keuangan, "Statistik Pasar Modal Syariah," 2020, 1-2.

e-ISSN: $2686-6633$ 
penelitian terhadap persepsi investor pemula dalam pengambilan keputusan pembelian saham syariah di Indonesia. Dari setiap indikator yang merupakan persepsi investor pemula, hampir semua informan dalam keputusan transaksinya mempertimbangkan indikator-indikator yang menunjukkan persepsi investor pemula dalam pengambilan keputusan pembelian saham syariah di Indonesia. Indikator yang dipakai oleh ketujuh belas informan oleh persepsi investor pemula adalah indikator neutral information yang mana informasi yang dijadikan sebagai bahan pertimbangan dalam mengambil keputusan untuk berinvestasi yaitu informasi yang berasal dari luar, seperti ulasan di media keuangan dan keadaan ekonomi secara umum, hal ini dikarenakan informasi tersebut lebih mudah didapatkan. ${ }^{27}$

Indikator kedua yang menjadi pertimbangan informan adalah accounting information dimana sepuluh dari tujuh belas informan mempertimbangkan indikator ini dalam keputusan investasinya. Accounting information ditunjukan oleh laporan keuangan perusahaan saat ini dan pendapatan perusahaan yang diharapkan digunakan sebagai alat analisis tradisional yang dianggap mampu mencerminkan tingkat keuntungan yang didapat, sehingga motivasi untuk memaksimalkan kekayaan tercapai. Indikator selanjutnya yang menjadi pertimbangan lima informan dalam keputusan transaksinya adalah social relevance dimana informan mempertimbangkan posisi

27 Agustin and Mawardi, "Perilaku Investor Muslim Dalam Bertransaksi Saham Di Pasar Modal." saham perusahaan dalam bursa. Sehingga dalam pembelian saham syariah berdasarkan minat masingmasing oleh informan. ${ }^{28}$

\subsection{Persepsi Investor Pemula Terhadap}

Pembelian Saham Syariah

Investasi saham khususnya saham syariah memiliki banyak pengaruh besar terutama bagi para investor untuk kekayaan jangka panjang mereka. Adapun investasi saham syariah dijadikan sebagai pilihan untuk berinvestasi dengan dilatarbelakangi berbagai faktor. Salah satu diantaranya adalah preferensi kriteria saham yang diantaranya:

a. Kegiatan perusahaan berdasarkan prinsip-prinsip Syariah

Preferensi dalam memilih saham yang memenuhi prinsip syariah yaitu dengan arahan Dewan Syariah mengenai Penerbitan Efek Syariah, dengan kegiatan usaha yang dinilai yaitu usaha yang tidak sesuai dengan prinsip Syariah, antara lain kegiatan usaha yang mengandung ketidak jelasan, perjudian, spekulasi, serta usaha jasa keuangan yang mengandung unsur ribawi. Gharar merupakan kegiatan jual beli yang mengandung ketidakjelasan mengenai adanya komoditas yang menjadi objek akad, ketidakjelasan akibat, dan bahaya yang mengancam antara untung dan rugi. Hal ini merugikan salah satu pihak. Sedangkan maysir (spekulasi) merupakan permainan yang di dalamnya disyaratkan sesuatu berupa materi yang berasal dari pihak yang kalah kepada pihak yang menang. ${ }^{29}$

\footnotetext{
28 Agustin and Mawardi.

29 Muhammad Jalari, olivia tiarthara
} Putri, and Agus Marimin, "Fundamental Analysis Dalam Pengambilan Keputusan e-ISSN: 2686-6633 
Hal ini terbukti dari hasil wawancara dengan informan penelitian yaitu Muhammad Roiyan, sebagai berikut:

“...Kriteria saham Syariah yang tepat yaitu dalam kegiatan usahanya perusahaan tidak bertentangan dengan prinsip Syariah..."

Pernyataan tersebut sesuai dengan POJK 15/POJK 04/2015 yang menjelaskan tentang prinsip-prinsip syariah di Pasar Modal. ${ }^{30}$ Adapun didapatkan hasil tidak jauh berbeda dengan Muhammad Roiyan. Atik Sa'adah mahasiswa yang berasal dari Mayong Jepara, dalam wawancaranya mengatakan:

“...Kegiatan perusahaan tidak bertentangan dengan prinsip syariah..."

Informan lain juga menunjukkan hasil yang hampir sama yaitu Yunni Aristyarini, dalam wawancara mengatakan:

"...Perusahaan yang melakukan aktivitas bisnisnya sesuai dengan syariah, baik kinerja perusahaan, produk maupun tanggungjawab sosialnya harus sesuai dengan prinsip syariah. Perusahaan yang sudah menerapkan prinsip syariah secara menyeluruh maka akan menjadikan stakeholder tertingginya Allah SWT, dengan begitu sebagai investor tentu lebih mempercayai kinerja perusahaannya..."

Investasi Saham Syariah Di Jakarta Islamic Index," Jurnal Education and Economics (JEE) 02, no. 04 (2019): 444-69.

30 Dewan Komisioner and Otoritas Jasa, "Otoritas Jasa Keuangan Republik Indonesia," 2015.
Pernyataan di atas menunjukkan makna yang hampir sama dengan penelitian yang dilakukan oleh Agustin dan Mawardi, dengan hasil penelitiannya yaitu bahwa perilaku investor muslim dalam aktivitas transaksi saham dibagi menjadi dua sudut pandang yaitu, investor yang mempertimbangkan agama dalam keputusan investasi mereka dan investor tidak mempertimbangkan agama dalam keputusan investasi mereka. Investor yang mempertimbangkan agama dalam keputusan investasi mereka lebih suka komposisi saham dari daftar indeks syariah yang masuk dan sifat investasi cenderung bersifat jangka panjang. Investor yang tidak mempertimbangkan agama dalam memilih saham keputusan investasinya berpadu dengan baik dalam indeks yang mematuhi syariah atau tidak. Sifat investasi investor yang tidak mempertimbangkan sifat jangka pendek agama. ${ }^{31}$

Hal ini bisa dilihat dari pernyataan oleh Muhammad Roiyan, Atik Sa'adah, dan Yunni Aristyarini, yang menyatakan bahwa perusahaan yang menerbitkan saham syariah dalam melakukan aktivitas bisnisnya sesuai dengan syariah, baik kinerja perusahaan, produk maupun tanggungjawab sosialnya harus sesuai dengan prinsip syariah. Adapun penelitian oleh Agustin dan Mawardi, dengan hasil penelitiannya yaitu bahwa perilaku investor muslim dalam aktivitas transaksi saham dengan berdasarkan sudut pandang yaitu, investor yang

31 Pramita Agustin and Imron Mawardi, "Perilaku Investor Muslim Dalam Bertransaksi Saham Di Pasar Modal," JESTT 1, no. 12 (2014): 874-892. 
mempertimbangkan agama dalam keputusan investasi mereka. Investor yang mempertimbangkan agama dalam keputusan investasi mereka lebih suka komposisi saham dari daftar indeks syariah yang masuk dan sifat investasi cenderung bersifat jangka panjang. ${ }^{32}$ Baik pernyataan yang diungkapkan oleh ketiga responden dengan penelitian oleh Agustin dan Mawardi sama-sama menjelaskan adanya persepsi dari seorang investor sebelum melakukan pembelian atau sebelum berinvestasi di saham Syariah, mereka lebih mempertimbangkan agama dalam keputusan berinvestasi mereka. Dengan tujuan terhindar dari transaksi yang mengandung unsur maghrib yaitu maisyir, gharar, risywah, serta kegiatan jasa keuangan yang mengandung unsur riba di dalamnya.

Prinsip syariah pada investasi saham syariah dijadikan sebagai pedoman dalam melakukan pembelian saham. Adapun preferensi kriteria saham syariah yang tepat yaitu emiten tidak melakukan kegiatan usahanya baik kegiatan memproduksi, mendistribusikan, memperdagangkan serta menyediakan barang atau jasa haram karena zatnya maupun barang atau jasa haram yang bukan karena zatnya (haram lighairi), serta dalam bertransaksi di dalamnya tidak ada unsur maghrib (maisir, gharar, risywah, dan riba) dan total utang berbasis bunga dibanding dengan total aset tidak lebih dari $45 \%$ atau total pendapatan bunga dan pendapatan tidak halal lainnya

32 Pramita Agustin and Imron Mawardi, "Perilaku Investor Muslim Dalam Bertransaksi Saham Di Pasar Modal," JESTT 1, no. 12 (2014): 874-892. dibandingkan dengan pendapatan usaha dan lain-lain tidak lebih dari 10\%.33 Sehingga bisa dikatakan bahwasannya investor pemula dalam melakukan pembelian saham syariah lebih mengedepankan kriteria saham yang berprinsip Syariah dalam melakukan investasi mereka.

b. Sebagai bentuk dukungan dalam memajukan perekonomian Indonesia

Surat berharga bukti penyertaan modal kepada perusahaan, pemegang saham mempunyai hak untuk mendapatkan deviden hasil dari usaha perusahaan dengan adanya bukti penyertaan tersebut disebut sebagai Saham Syariah. Sinergi antar inverstor mendukung perekonomian Indonesia, di mana kemajuan perekonomian Indonesia terwujud dengan adanya bursa efek yang sehat, good governance perusahaan yang baik, serta meningkatnya jumlah emiten dari periode ke periode. Hal ini sesuai dengan hasil wawancara dengan beberapa informan penelitian yaitu Halwa Intan, mengatakan bahwa:

"...Saya lebih memilih untuk berinvestasi di saham Syariah yaitu sebagai bentuk dukungan untuk memajukan saham Syariah (ekonomi Islam di Indonesia) ..."

Pernyataan Halwa Intan tersebut didapatkan data yang menunjukkan bahwasanya dengan berinvestasi di saham Syariah secara tidak langsung adalah sebagai bentuk dukungan dalam memajukan ekonomi Islam di

33 Bursa Efek Indonesia, "Produk Syariah," Jakarta Selatan, n.d.

e-ISSN: $2686-6633$ 
Indonesia. ${ }^{34}$ Hal tersebut berlainan dengan penelitian yang dilakukan oleh Dihin Sepyato, dkk. bahwasannya faktor yang dominan dalam pengambilan keputusan penilaian prospek saham ada pada pengetahuan fundamental dibandingkan aspek teknikal. Adapun beberapa hal yang mempunyai pengaruh yang signifikan terhadap keputusan membeli saham syariah, seperti penilaian prospek saham yang didasarkan pada manfaat informasi harga, informasi keuangan, dan faktor yang hubungan manusia dengan Tuhannya serta hubungan dengan sesama manusia. ${ }^{35}$

Adapun hal tersebut dilihat dari adanya perubahan harga saham. Perubahan ini nantinya dapat memengaruhi pendapatan saham syariah juga dapat memengaruhi perkembangan perekonomian. Pertumbuhan ekonomi yang meningkat dapat menigkatkan daya beli konsumen terhadap produk-produk, sehingga mengakibatkan profitabilitas perusahaan menjadi meningkat. Adanya peningkatan tersebut, maka dapat meningkatkan investor untuk berinvestasi, sehingga dapat meningkatkan harga saham. Oleh karena itu, pendapatan dari sektor saham Syariah sendiri, yang mana masih dalam lingkup perusahaan Syariah, sehingga mempunyai pengaruh tidak secara

${ }^{34}$ Nur Hakiki Siregar, "Pengaruh Saham Syariah, Sukuk, Dan Reksadana Syariah Terhadap Pertumbuhan Ekonomi Nasional" (UIN Sumatera Utara Medan, 2018).

35 Septyato, Sudarwan, and Dewanto, "Model Perilaku Syariah Dalam Pengambilan Keputusan Investasi Pada Investor Muslim Di Bursa Efek Indonesia." langsung atau menyeluruh terhadap pertumbuhan ekonomi di Indonesia.

c. Pola berfikir secara fundamental

Selain keputusan pembelian saham syariah berdasarkan prinsip syariah dan persepsi yang merupakan bentuk dukungan dalam memajukan Ekonomi Islam di Indonesia, berfikir secara fundamental juga dapat memengaruhi keputusan pembelian saham syariah. Dibuktikan dengan pernyataan Avip Wijanarko dan Yusuf Saepul Bahri:

"...saham yang memiliki fundamental perusahaan bagus dan sektor usaha yang potensial..."

Pernyataan responden dikuatkan oleh Buku Karya Sepyato, Sudarwan dan Dewanto, yang menjelaskan bahwa analisis fundamental adalah analisis terhadap kondisi suatu perusahaaan, baik secara ekonomi (dalam laporan keuangannya), maupun secara kualitas seperti kinerja, manajemen, serta potensi perusahaan di masa depan. ${ }^{36}$ Pernyataan tersebut jika dibandingkan dengan penelitian yang penelitian oleh Tannadi dkk. yang mengungkapkan bahwa faktor literasi keuangan, nilai pribadi, dan penghindaran risiko berpengaruh terhadap keputusan investasi, menunjukkan bahwa terdapat kesamaan yaitu faktor literasi keuangan yang berhubungan dengan berfikir fundamental, yang mana sama-sama mempunyai pengaruh dalam menentukan keputusan untuk berinvestasi. ${ }^{37}$

36Tannadi and Friendy, Ilmu Saham.

37Darmawan, Nurwahidin, and Anwar, "'Analisis Faktor-Faktor Yang Memengaruhi Keputusan Investasi Di Pasar Modal Syariah.'" e-ISSN: 2686-6633 
Analisis ini menitik beratkan pada data-data kunci dalam laporan keuangan perusahaan untuk memperhitungkan apakah harga saham sudah diapresiasikan secara akurat. Analisis fundamental adalah metode analisis saham dengan menganalisa informasi yang berhubungan dengan kinerja perusahaan, financial statement pada umumnya dijadikan sebagai sumber utama dalam analisis ini termasuk penggunaan rasio-rasio keuangan. 38

Sebagai investor pemula, ketika kita akan menanamkan modal dengan jangka waktu yang lama, muali dari satu tahun atau bahkan lebih hingga tidak ada batasan waktu. Oleh karena itu, berfikir fundamental menjadi sesuatu yang wajib dilakukan. ${ }^{39}$

\section{Kesimpulan}

Dari hasil penelitian dan pembahasan mengenai persepsi investor pemula terhadap minat beli saham syariah di Indonesia, yang mana saham Syariah berfungsi sebagai sumber kekayaan jangka panjang oleh investor pemula yang telah diuraikan pada bab sebelumnya, maka dapat diambil kesimpulan bahwa persepsi investor pemula terhadap minat beli saham Syariah di Indonesia yaitu indikator neutral information, accounting information, social relevance. Dari indikator-indikator tersebut didapatkan hasil sebagai berikut:

Pertama, investor pemula lebih mempertimbangkan prinsip Syariah

38 Jalari, Putri, and Marimin, "Fundamental Analysis Dalam Pengambilan Keputusan Investasi Saham Syariah Di Jakarta Islamic Index."

39 Tannadi and Friendy, Ilmu Saham. dalam melakukan transaksi pembelian saham. Kedua, sebagai bentuk dukungan dalam memajukan ekonomi Islam di Indonesia, dengan berinvestasi di saham Syariah diharapkan adanya perubahan harga saham yang nantinya akan mempengaruhi pendapatan saham Syariah sehingga dapat mempengaruhi perkembangan perekonomian. Ketiga, mengedepankan berfikir fundamental menjadi sesuatu yang wajib dilakukan, sehingga dapat mengurangi jika terjadinya kerugian yang diakibatkan risiko-risiko yang ada.

\section{Daftar Pustaka}

Agustin, Pramita, and Imron Mawardi. "JESTT Vol. 1 No. 12 Desember 2014." JESTT 1, no. 12 (2014): 87492.

- - . "Perilaku Investor Muslim Dalam Bertransaksi Saham Di Pasar Modal." JESTT 1, no. 12 (2014): 87492.

Alfian, Ian. "Analisis Pengaruh Label Halal, Brand Dan Harga Terhadap Keputusan Pembelian Di Kota Medan." At-Tawassuth 2, no. 1 (2017): 122-45.

Arikunto, Suharismi. Prosedur Penelitian Suatu Pendekatan Praktik (VI). Rineka Cipta, 2010.

Betty, M, Susanti, and Y Yuli. "Perilaku Investor Muslimah Di Pasar Modal Syariah Di Lampung." Jurnal Bisnis Darmajaya 4, no. 1 (2018): 26-44.

Darmawan, Taufan, Nurwahidin, and Saiful Anwar. "'Analisis FaktorFaktor Yang Memengaruhi Keputusan Investasi Di Pasar Modal Syariah.'" Jurnal Middle East and Islamic Studies 6, no. 2 (2019): 192-214. 
Faniyah, Iyah. “Investasi Syariah Dalam Pembangunan Ekonomi Indonesia." In Deepublish, 1-108, 2017.

Harahap, Sukri, and Amelia Murni. "Kinerja Pasar Modal Syariah Tetap Positif Di Tengah Pandemi Corona." Kitakini.news, 2020. https://kitakini.news/58165/kinerj a-pasar-modal-syariah-tetap-positifdi-tengah-pandemi-corona.

Haryanto. "Investasi Saham Syariah Saat Ramadan, Cuan Gak Yah?" CNBN Indonesia, 2020. https://www.cnbnindonesia.com/s yariah/20200429135923-29-

155260/investasi-saham-syariahsaat-ramadan-cuan-gak-yah.

Heryanto, Imam. "Analisis Pengaruh Produk, Harga, Distribusi, Dan Promosi Terhadap Keputusan Pembelian Serta Implikasinya Pada Kepuasan Pelanggan." Jurnal Ekonomi, Bisnis, E Entrepreeurship 9, no. 2 (2015): 80-101.

Hogan, Nicky. Yuk Nabung Saham. Jakarta: PT Elex Media Komputindo, n.d.

- - . Yuk Nabung Saham Selamat Datang, Investor Indonesia! Jakarta: PT Elex Media Komputindo, 2016.

Indonesia, Bursa Efek. "Produk Syariah." Jakarta Selatan, n.d.

Intan, Novita. "Investasi Syariah Meningkat, BEI Kantongi 70.132 Investor." Republika.co.id, 2020. https://republika.co.id/berita/q65 0zz370/investasi-syariahmeningkat-bei-kantongi-70132investor.

Jalari, Muhammad, olivia tiarthara Putri, and Agus Marimin. "Fundamental Analysis Dalam Pengambilan Keputusan Investasi Saham Syariah
Di Jakarta Islamic Index." Jurnal Education and Economics (JEE) 02, no. 04 (2019): 444-69.

Komisioner, Dewan, and Otoritas Jasa. "Otoritas Jasa Keuangan Republik Indonesia," 2015.

Kreitner, Robert, Angelo Kinicki, and Nina Cole. Organizational Behaviour Key Concepts, Skills, and Best Practices. Edited by Joanna Cotton. 2nd Canadi. McGraw-Hill Ryerson, 2003.

Marjudin. "BEI: Saham-Saham Syariah Mulai Jadi Incaran Banyak Investor." Ipotnews, 2019. https://www.indopremier.com/ip otnews/newDetail.php?jdl=BEI

Saham_Syariah_Mulai_Jadi_Incaran _Banyak_Investor\&news_id=112653 \&group_news=IPOTNEWS\&news_ date $=$ \&taging_subtype $=$ MARKETO VERVIEW\&name $=\&$ search $=y \_$gene ral\&q=BEI, \&halaman +1 .

Oktaviani, Retno Fuji. "Index Harga Saham Islamic Internasional Terhadap Jakarta Islamic Index." Jurnal Ekonomika Dan Manajemen 6, no. 1 (2017): 1-15.

Schermerchon, John R., James G. Hunt, and Richard N. Osborn. Organizational Behavior. Edited by Inc. John Wiley \& Sons. 7th ed. United States of America, 2002.

Septyato, Dihin, Sudarwan, and Ignatius Joko Dewanto. "Model Perilaku Syariah Dalam Pengambilan Keputusan Investasi Pada Investor Muslim Di Bursa Efek Indonesia." Prosiding Seminar Nasional, 2016, 425-37.

www.jp.feb.unsoed.ac.id/index.ph p/sca-1/article/viewFile/306/311. Singarimbun, Masri, and Sofyan Efendy. 
Metode Penelitian. Jakarta: Pustaka LP3S, 1993.

Siregar, Nur Hakiki. "Pengaruh Saham

Syariah, Sukuk, Dan Reksadana

Syariah Terhadap Pertumbuhan

Ekonomi Nasional." UIN Sumatera

Utara Medan, 2018.

Syariah, Direktorat Pasar Modal, and

Otoritas Jasa Keuangan. "Statistik

Pasar Modal Syariah," 2020, 1-2.

Tannadi, Belvin, and Friendy. Ilmu

Saham. Binjai: PT Elex Media

Komputindo, 2019. 